\title{
Detection of Clonal Relationship Between Carbapenem-resistant Acinetobacter baumannii Isolates in an University Hospital
}

\author{
Bir Üniversite Hastanesinde Izole Edilen Karbapenem Dirençli Acinetobacter baumannii \\ Suşları Arasındaki Klonal llişkinin Saptanması
}

\author{
(1) Yasemin KIRIK ${ }^{1}$, (1) Kutbeddin DEMIRDAĞ², (1) Barış OTLU ${ }^{3}$, (1) Ayşe SAĞMAK TARTAR ${ }^{2}$, (1) Ayhan AKBULUT ${ }^{2}$ \\ 1 Fethi Sekin City Hospital, Clinic of Infection Diseases and Clinical Microbiology, Elazı̆̆, Turkey \\ 2Firat University Faculty of Medicine, Department of Infectious Diseases and Clinical Microbiology, Elazığ, Turkey \\ 3inönü University Faculty of Medicine, Department of Medical Microbiology, Malatya, Turkey
}

\section{Abstract}

Introduction: Nosocomial infections continue to be an important health problem since they seriously increase the rate of mortality and morbidity as well as hospitalization period and treatment costs. Acinetobacter spp. have an important place among the factors that cause hospital infections. Fast and accurate detection of Acinetobacter baumannii outbreaks is important in the treatment and control of epidemic infections. In our study, it was aimed to investigate the molecular similarities of carbapenem resistant $A$. baumannii isolates isolated as hospital infectious agents with Pulsed-Field Gel Electrophoresis (PFGE) method.

Materials and Methods: This study was conducted in a medical center to examine the genetic relationship of a specific agent group detected in the non-pandemic period and is a cross-sectional study. In our study, the molecular similarities of 93 carbapenem resistant A. baumannii isolates isolated as hospital infectious agents from various clinical materials sent to Firat University Hospital Central Laboratory and Infectious Diseases Department Laboratory between December 1, 2013 and June 30, 2014 were investigated with PFGE method.

Results: A. baumannii strains showed 30 different PFGE profiles. Clonally related strains were included in seven different clusters. Eighty of 93 A. baumannii strains in total were included in any cluster. The clustering rate of the strains was found to be $86 \%$. When the isolate dates of 55 strains in 1 cluster with the highest number of isolates were examined in our study, it was seen that this clone survived in our hospital for about five months. Conclusion: This study showed that $A$. baumannii strains isolated as nosocomial infection agents can survive for a long time. It was thought that carbapenem resistance spread horizontally among Acinetobacter spp. It was concluded that the necessity of training activities for infection control measures and compliance should be examined, and antibiotic use policies should be revised in terms of carbapenem resistance.

Keywords: Acinetobacter baumannii, carbapenem-resistance, PFGE, genotyping

\section{Öz}

Giriş: Hastane enfeksiyonları; morbidite ve mortalite oranlarını, hastanede kalış süresini ve tedavi maliyetini artırdığı için, önemli bir sağlık problemi olmaya devam etmektedir. Acinetobacter spp. hastane enfeksiyonlarına yol açan etkenler içinde önemli bir yer tutmaktadır. Acinetobacter baumannii salgınlarının kaynağının doğru ve hızlı tespiti, enfeksiyonun tedavisi ve salgının kontrolü açısından önemlidir. Çalışmamızda hastane enfeksiyon etkeni olarak izole edilen karbapenem dirençli A. baumannii izolatlarının Pulsed-Field Gel Electrophoresis (PFGE) yöntemiyle moleküler benzerliklerinin araştırılması amaçlandı.

Gereç ve Yöntem: Bu çalışma bir tıp merkezinde salgın dışı dönemde saptanan özellikli bir etken grubunun genetik ilişkisinin incelenmesi amacıyla yapılmıştır ve kesitsel bir araştırmadır. Çalışmamızda Fırat Üniversitesi Hastanesi Merkez Laboratuvarı ile Enfeksiyon Hastalıkları Anabilim Dalı Laboratuvarı'na 1 Aralık 2013-30 Haziran 2014 tarihleri arasında gönderilen çeşitli klinik materyallerden hastane enfeksiyon etkeni olarak izole edilen 93 adet karbapenem dirençli $A$. baumannii izolatının PFGE yöntemiyle moleküler benzerlikleri araştırıldı.

Cite this article as: Kırık Y, Demirdağ K, Otlu B, Sağmak Tartar A, Akbulut A. Detection of Clonal Relationship Between Carbapenem-resistant Acinetobacter baumannii Isolates in an University Hospital. Mediterr J Infect Microb Antimicrob. 2021;10:21. 
Bulgular: A. baumannii suşları 30 farklı PFGE profili gösterdi. Klonal yönden ilişkili suşlar, yedi farklı küme içerisinde yer aldı. Toplam 93 A. baumannii suşunun 80'i herhangi bir küme içerisinde yer aldı. Suşların kümeleşme oranı \%86 olarak bulundu. Çalışmamızda en fazla izolat sayısına sahip 1 kümesinde yer alan 55 suşun izolasyon tarihleri incelendiğinde, bu klonun hastanemizde yaklaşık beş ay varlığını sürdürdüğü görüldü.

Sonuç: Bu çalışma hastane enfeksiyonu etkeni olarak izole ettiğimiz A. baumannii suşlarının, varlığını uzun süre devam ettirebildiğini göstermiştir. Karbapenem direncinin Acinetobacter'ler arasında horizontal yayılım gösterdiği düşünüldü. Enfeksiyon kontrol önlemlerine yönelik eğitim faaliyetlerinin gerekliliği ve uyumun irdelenmesi, karbapenem direnci açısından antibiyotik kullanım politikalarının tekrar gözden geçirilmesi gerektiği sonucuna varıldı.

Anahtar Kelimeler: Acinetobacter baumannii, karbapenem direnci, PFGE, genotipleme

\section{Introduction}

Nosocomial infections caused by multi-drug resistant (MDR) Gram-negative bacilli have been an important problem in recent years $^{[1]}$. Acinetobacter spp., especially Acinetobacter baumannii, have been more frequently isolated as an opportunistic cause of hospital infection in patients hospitalized in intensive care unit (ICU), requiring respiratory support, having a weak immune system, receiving long-term antibiotic therapy or chemotherapy, and undergoing surgical intervention ${ }^{[2]}$. Acinetobacter spp. play role as agents in bacteremia, secondary meningitis, urinary tract infections and pneumonia. They are nonfermentative, oxidase negative, indole negative, catalase positive, immobile, non-nitrate reducing, obligatory aerobic Gram-negative microorganisms that grow at $35-37^{\circ} \mathrm{C}$.

Increasing resistance to antimicrobial agents used in the treatment of infections caused by Acinetobacter spp. has become an important health problem both in our country and in other countries ${ }^{[3,4]}$. Carbapenems are beta-lactam-type drugs of choice for the treatment of Acinetobacter infections, but recently resistance to these antimicrobial drugs has also increased $^{[5]}$. When studies on antibiotic susceptibility of Gramnegative microorganisms conducted in our country are examined, it is observed that over the years, there has been an increase in the strains of multi-drug resistant Acinetobacter spp. including carbapenems, multi-drug resistant $P$. aeruginosa, and extended spectrum beta-lactamase producing Enterobacteriaceae ${ }^{[6,7]}$. In studies conducted in Turkey, statistically significant decrease has been observed in the Staphylococcus aureus (S. aureus) and methicillin-resistant $S$. aureus isolates in ICUs over the years ${ }^{[8]}$. While the rates of methicillin-resistant $S$. aureus infections have been significantly reduced by infection control measures and education, both the incidences of Acinetobacter infections and antibiotic resistance have increased.

Acinetobacter infections are important in terms of causing epidemics within the hospitals, between hospitals and even between countries. Molecular typing methods performed to reveal the clonal relationship between isolates of the same species are evaluated in the light of epidemiological information and it is accepted that the isolates originate from two same or different sources ${ }^{[9]}$. Although there are various molecular methods, Pulsed-Field Gel Electrophoresis (PFGE) seems to be the most suitable method that can be used in most bacterial species $^{[10]}$. Since PFGE has high reproducibility, this method has been accepted by many researchers as the gold standard in molecular methods. Our aim in this study was to determine the clonal relationship between Acinetobacter isolates, of which mortality rate was increasing day by day, which was difficult to control and which was the cause of nosocomial infection, by PFGE method.

\section{Materials and Methods}

This study was carried out in accordance with the Helsinki Declaration. This study was approved by the Non-Invasive Research Ethics Committee of the Firat University, Faculty of Medicine with the decision number and date 12.11.2013-04.

\section{Study Design}

It was a cross-sectional study to examine the genetic relationship between carbapenem-resistant $A$. baumannii strains detected in the non-epidemic period at the Firat University Hospital. Ninety three $A$. baumannii isolates isolated from various clinical materials sent to the Firat University Hospital Central Laboratory and Infectious Diseases Department Laboratory between December 2013 and June 2014 were included in the study. The study was planned as a prospective study. If more than one $A$. baumannii was isolated from the same patient, only one of these strains was included in the study. In case of growth of carbapenem-resistant $A$. baumannii, the patient was evaluated in bed and the culture result was evaluated in terms of infection, contamination and colonization. Strains determined as nosocomial infection agents were included in the study. The infections that occurred 48-72 hours after hospitalization, 10 days after discharge, 30 days after surgery, and within 90 days if an implant was placed in surgery were considered hospital infections.

Nosocomial infection diagnosis was made according to the following criteria:

Pneumonia: Purulent sputum with ral or dullness or change in sputum quality, growth in endotracheal aspirate, bronchoalveolar lavage or sputum culture, the presence of 
consolidation, cavitation or pleural effusion with progressive infiltrations on chest radiograph.

Blood stream infection: Producing the same agent in two or more blood cultures, fever, chills or hypotension.

Urinary system infection: Symptoms such as dysuria, pollakiuria or urgency etc. and growth of $10^{5}$ or more microorganisms in urine culture, fever that could not be explained by any other reason in patients with urinary catheter suprapubic tenderness, costovertebral angle sensitivity detected in physical examination, growth of $10^{5}$ or more microorganisms in urine culture.

Meningitis: Growth of a microorganism in cerebrospinal fluid with appropriate clinical picture and physical examination.

Surgical site infection: Localized pain, localized hyperemia, localized increased temperature, and purulent discharge in the surgical area.

Culture, Identification and Susceptibility Tests for $A$. baumannii

Samples taken from patients under appropriate conditions (such as blood, bronchoalveolar lavage, tracheal aspirate, urine, wound, pleural fluid and cerebrospinal fluid) were included in our study.

Microscopically Gram-negative bacilli or coccobacillus forming colorless colonies in eosin methylen-blue (EMB) medium were accepted as suspicious for $A$. baumannii and were passaged into sheep blood agar and EMB media in order to obtain a pure colony. Strains identified as A. baumannii with Vitek-2 (BioMerieuxUSA) automated systems were included in the study.

Antibiotic susceptibilities of the strains included in the study were made according to the Kirby Bauer disc diffusion method and the results were interpreted according to the Clinical and Laboratory Standards Institute standards ${ }^{[11]}$. PFGE was applied to carbapenem-resistant strains of $A$. baumanniiat the Microbiology Laboratory of İnönü University, Faculty of Medicine.

\section{Typing with Pulsed-Field Gel Electrophoresis}

Isolation and deproteinization procedures for variable area gel electrophoresis were performed with the protocol prepared by Durmaz et al. ${ }^{[12]}$. DNA was cut with $10 \mathrm{U} / \mu \mathrm{l}$ Apal (Fermentas, Lithuania) enzyme, run in $1 \%$ agarose in CHEF-DRII system (Bio-Rad Laboratories, Belgium) at $14{ }^{\circ} \mathrm{C}$ and $6 \mathrm{~V} / \mathrm{cm}^{2}$ for 20 hours. DNA band profiles were analyzed using the GelCompar II software system. Dendrogram analysis of PFGE profiles was performed using the 'Unweighted pair group method with mathematical averaging' method and Dice similarity coefficient. In the evaluation, the tolerance was taken as $1 \%$. In this statistical analysis, $95-100 \%$ similarity was considered as "related-indistinguishable", 90-95\% as "possibly related", and $<90 \%$ as "unrelated".

\section{Statistical Analysis}

The IBM Statistical Package for the Social Sciences (SPSS) Statistics 22 version package program (SPSS inc., Chicago, IL, USA) was used for statistical analysis. Classified data are given as frequency and percentage.

\section{Results}

Ninety three carbapenem resistant $A$. baumannii strains as nosocomial infection agents were included in the study. Sixty two of the isolated clinical specimens belonged to male patients and 31 to female patients. Acinetobacter baumannii grew in tracheal aspirate culture in 71 patients (76.3\%), wound culture in $12(12.9 \%)$ patients, urine culture in four $(4.3 \%)$ patients, bronchoalveolar lavage in two patients, blood in one (1.07\%) patient, pleural fluid in one (1.07) patient, sputum in one $(1.07 \%)$ patient, and cerebrospinal fluid in one (1.07\%) patient.

The unit where Acinetobacter baumannii was mostly isolated was the internal medicine intensive care unit with $44.08 \%$ (41/93). Thirty seven (39.7\%) were isolated in anesthesia ICU, four $(4.3 \%)$ in plastic surgery, two $(2.1 \%)$ in each of urology, orthopedics and gynecology units, one (1.07\%) in each of neurosurgery, neurosurgery ICU, and hematology units.

The most common infection caused by Acinetobacter baumannii was detected as pneumonia in $75(80.6 \%)$ patients. Surgical site infection was detected in $11(11.8 \%)$, urinary infection in four (4.3\%), primary blood circulation infection in one (1.07\%), meningitis in one (1.07\%), and osteomyelitis in one (1.07\%) patient.

The 93 A. baumannii strains that were typed showed 30 different PFGE profiles (Figure 1). Clonally related strains were located in seven different clusters. Eighty of 93 A. baumannii strains included in the study were located in any of the seven different clusters shown. The clustering rate of the strains was $86 \%$.

The largest cluster was the cluster coded with "1" in which 55 isolates were located. This was followed by clusters $2(10$ isolates), 4 (six isolates), 7 (three isolates), 3 (two isolates), 5 (two isolates), and 6 (two isolates), respectively.

When the isolate dates of 55 strains in cluster 1 with the highest number of isolates were examined in our study, it was seen that this clone survived in our hospital for about five months. Of the isolates in this cluster, 45\% were isolated from the internal medicine ICU, 40\% from the anesthesia ICU, and 15\% from the samples sent from other clinical units.

Samples of 10 strains in cluster 2 belonged to patients in the internal medicine ICU, anesthesia, urology and hematology units and all were isolated in the same month. This clone survived in our hospital for one month. 


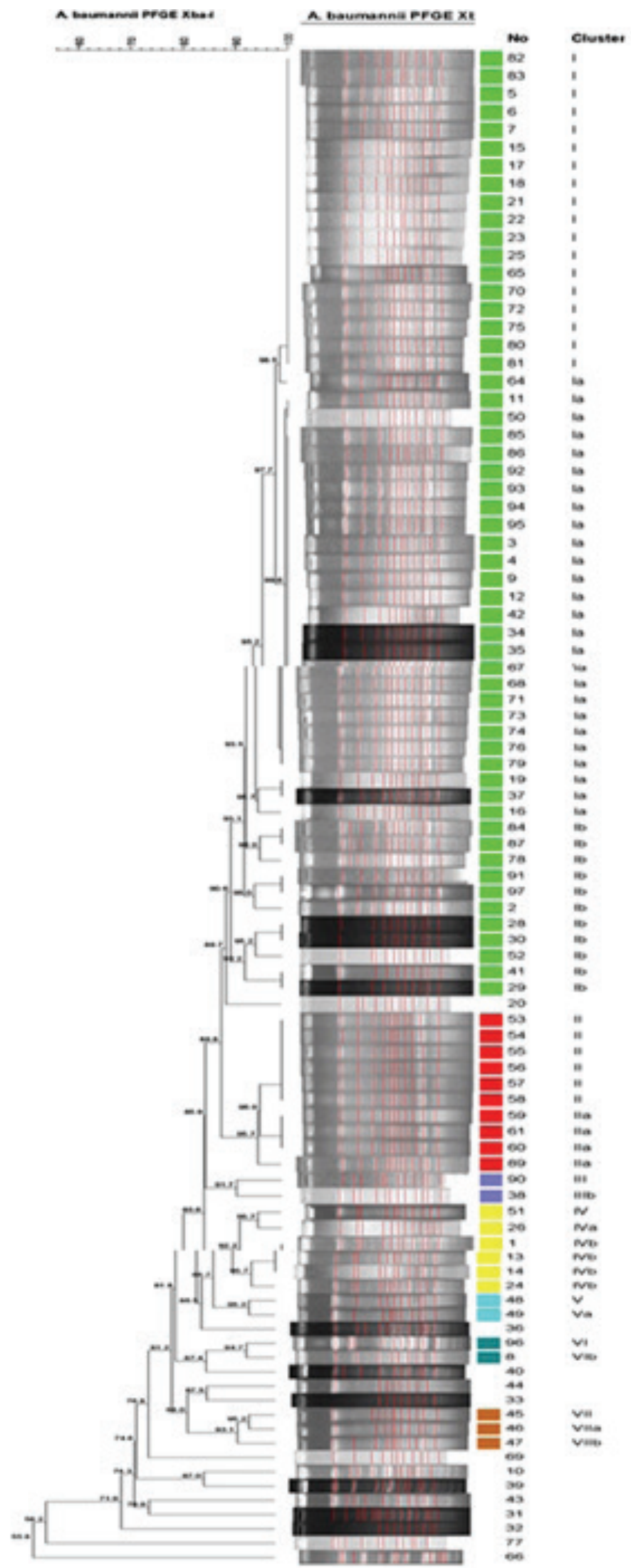

Figure 1. Dendrogram image obtained with Pulsed-Field Gel Electrophoresis
Cluster 3 had two strains from the anesthesia ICU, but these two strains were isolated at different times with an interval of four months.

In cluster 4, six isolates were grown from samples from the anesthesia and internal medicine ICUs and urology clinic and remained in our hospital for two months.

Cluster 5 had two strains isolated from the anesthesia ICU in the same month.

In cluster 6, two strains sent from the internal medicine ICU were isolated at different times with an interval of four months.

All three isolates in cluster 7 were detected in the same month and two were isolated from the samples sent from the internal medicine ICU and one from the anesthesia ICU.

\section{Discussion}

Acinetobacter spp. was considered as a low-virulence microorganism with a higher colonization capacity than infectious capacity until recently. However, today, hospitalacquired infections due to Acinetobacter species, especially $A$. baumannii, are increasing rapidly all over the world ${ }^{[13]}$. Due to its resistance to dryness and disinfectants; the fact that it can maintain its viability for a long time in medical devices and hospital surfaces, the increasing rates of multiple antibiotic resistance including carbapenem resistance, and its ability to lead to epidemics especially in ICUs, increase the importance of A. baumannii among the agents of hospital infection ${ }^{[14,15]}$.

There are several methods based on DNA analysis that provide information about the genetic relationships of isolates of the same species. Although different molecular typing methods have been tried to investigate the clonal relationship between bacteria, it is accepted that the PFGE method has the highest discrimination power among them ${ }^{[16]}$. Cetin et al. ${ }^{[17]}$ investigated the epidemiological characterization of nosocomial A. baumannii strains using the PFGE method in a university hospital. It was determined that type A and type K PFGE strains constituted $44 \%$ of the strains and 13 antibiotyping were determined. It was thought that especially two epidemic clones among the strains, most of which had multiple antibiotic resistance, might cause epidemics. In our study, PFGE method was used to investigate the clonal relationship between carbapenem resistant $A$. baumannii isolates isolated from various clinics in our hospital. A total of 93 A. baumannii isolates showed 30 different PFGE profiles by this method. The "clustering rate", which was an indicator of clonal affinity between the isolates, was found to be $86 \%$. This clustering rate is an important indicator of the very high clonal affinity between isolates, in other words, the high rate of cross contamination among patients. Clonal-related strains remained in our hospital for a long time and caused hospital infections 
at various times. For example, 55 strains in cluster 1 with the highest number of isolates, survived for about five months in our hospital, and the isolates were mainly produced in samples from the internal medicine and anesthesia ICUs. These results showed that especially resistant epidemic clones could stay in the hospital environment for a long time and could be transported from patient to patient if precautions were not taken.

Potential risk factors for nosocomial infection with multidrugresistant Acinetobacter are; long stay in ICU, underlying comorbid conditions, $3^{\text {rd }}$ generation cephalosporin and carbapenem use, hospital size and urinary catheterization. In our study, carbapenem-resistant isolates were mostly detected in samples from ICUs.

The fact that Acinetobacter type bacteria are resistant to environmental conditions is one of the important reasons that make it difficult to fight infections caused by this species. In order to reduce the rates of infection with $A$. baumannii and with other problematic microorganism; cross contamination, primarily in the ICU, should be prevented, personnel should be trained at frequent intervals for this purpose, and materials used jointly among patients should be reduced. Attention should be paid to hand hygiene and the use of gloves. Patients who recover and are transfered to the services should be taken into contact isolation until surveillance cultures are finalized in their new services and the transmission of problematic microorganisms to other patients in the service should be prevented. Surveillance studies should be carried out in ICUs to detect outbreaks in a timely manner.

The limitation of our study was that most of the strains included in the study were obtained from the ICUs and covered a short period of seven months.

\section{Conclusion}

As a result; this study showed that the A. baumannii strains isolated as nosocomial infection agents could survive for as long as five months. It was thought that carbapenem resistance spread horizontally among Acinetobacteria. It was concluded that the necessity of training activities for infection control measures and compliance should be highlighted and antibiotic usage policies should be reviewed again.

\section{Ethics}

Ethics Committee Approval: This study was approved by the Non-Invasive Research Ethics Committee of the Firat University, Faculty of Medicine with the decision number and date 12.11.2013-04.

Informed Consent: It is laboratory work done on microorganisms.
Peer-review: Externally and internally peer-reviewed.

\section{Authorship Contributions}

Surgical and Medical Practices: Y.K., B.O., Concept:Y.K., K.D., A.K., Design: Y.K., K.D., B.O., A.K., Data Collection or Processing: Y.K., A.S.T., Analysis or Interpretation: Y.K., K.D., B.O., A.S.T., A.K., Literature Search: Y.K., K.D., Writing: Y.K., A.S.T.

Conflict of Interest: No conflict of interest was declared by the authors.

Financial Disclosure: The authors declared that this study received no financial support.

\section{References}

1. Berezin BE, Towner KJ. Acinetobacter spp. as nosocomial pathogens: microbiological, clinical and epidemiological features. Clin Microbiol Rev. 1996;9:148-65.

2. Chastre J. Infections due to Acinetobacter baumannii in the ICU. Semin Respir Crit Care Med. 2003;24:69-78.

3. Fagon JY, Chastre J, Nance AJ, Montravers P, Novara A, Gibert J. Nosocomial pneumonia in ventilated patients: a cohort study evaluating attributable mortality and hospital stay. Am J Med. 1993;94:281-8.

4. Afzal-Shah $M$, Livermore DM. Worldwide emergence of carbapenemresistant Acinetobacter spp. J Antimicrob Chemother. 1998;41:576-7.

5. Wisplinghoff $\mathrm{H}$, Bischoff $\mathrm{T}$, Tallent $\mathrm{SM}$, Seifert $\mathrm{H}$, Wenzel RP, Edmond MB. Nosocomial bloodstream infections in US hospitals: analysis of 24179 cases from a prospective nationwide surveillance study. Clin Infect Dis. 2004;39:9-17.

6. Gür D, Gülay Z, Arıkan Akan Ö, Aktaş Z, Kayacan ÇB, Çakıcı Ö, Eraç B, Gültekin $M$, Öğünç D, Söyletir G, Ünal N, Uysal S. Resıstance to newer beta-lactams and related ESBL types in Gram-negative nosocomial isolates In Turkish hospitals: results of the multicentre Hitit study. Mikrobiol Bul. 2008;42:537-44.

7. Ertürk A, Çopur Çiçek $A$, Köksal E, Şentürk Köksal Z, Özyurt S. Yoğun bakım ünitesinde yatan hastaların çeşitli klinik örneklerinden izole edilen mikroorganizmalar ve antibiyotik duyarlılıkları. ANKEM Derg. 2012;26:1-9.

8. Inan A, Ozgultekin A, Akcay SS, Engin DÖ, Turan G, Ceran N, Dinçer E, Aksaray $S$, Göktaş $P$, Erdem I. Alterations in bacterial spectrum and increasing resistance rates in isolated microorganisms derived from deviceassociated infections in an intensive care unit of a teaching hospital in İstanbul (2004-2010). Jpn J Infect Dis. 2012;65:146-51.

9. Durmaz R. Moleküler epidemiyolojinin prensipleri. İçinde: Durmaz R (ed). Uygulamalı moleküler mikrobiyoloji. 2. baskı. İstanbul: Nobel Tıp Kitabevleri, 2001:139-47.

10. Tenover FC, Arbeit RD, Goering RV, Mickelsen PA, Murray BE, Persing $\mathrm{DH}$, Swaminathan B. Interpreting chromosomal DNA restriction patterns produced by pulsed-field gel electrophoresis: criteria for bacterial strain typing. J Clin Microbiol. 1995;33:2233-9.

11. Clinical and Laboratory Standards Institute (CLSI). Methods for antimicrobial susceptibility testing of anaerobic bacteria. Approved Standard, 8 ${ }^{\text {th }}$ ed. CLSI Document M11-A8. Wayne, PA: CLSI, 2012.

12. Durmaz R, Otlu B, Çalıskan A, Gürsoy N. Acinetobacter baumannii, Escherichia coli ve Klebsiella türlerinin moleküler tiplendirmesinde kullanılabilecek kısa süreli "Pulsed-Field gel" elektroforez (PFGE) protokolü. ANKEM Derg. 2007;21:113-7.

13. Routsi C, Pratikaki M, Platsouka E, Sotiropoulou C, Nanas S, Markaki V Vrettou C, Paniara O, Giamarellou H, Roussos C. Carbapenem-resistant versus carbapenem-susceptible Acinetobacter baumannii bacteremia in 
a Greek intensive care unit: risk factors, clinical features and outcomes. Infection. 2010;38:173-80.

14. Souli M, Galani I, Giamarellou H. Emergence of extensively drug resistant and pandrug-resistant Gram-negative bacilli in Europe. Euro Surveill. 2008;13:19045.

15. Badave GK, Dhananjay K. Biofilm producing multidrug resistant Acinetobacter baumannii: an emerging challenge, J Clin Diagn Res. 2015;9:DC08-10.
16. Durmaz R. Dirençli bakteri suşları arasındaki klonal ilişkinin belirlenmesi. ANKEM Derg. 2007;21(Ek 2):178-83.

17. Cetin ES, Durmaz R, Tetik T, Otlu B, Kaya S, Calişkan A. Epidemiologic characterization of nosocomial Acinetobacter baumannii infections in a Turkish university hospital by pulsed-field gel electrophoresis. Am J Infect Control. 2009;37:56-64. 